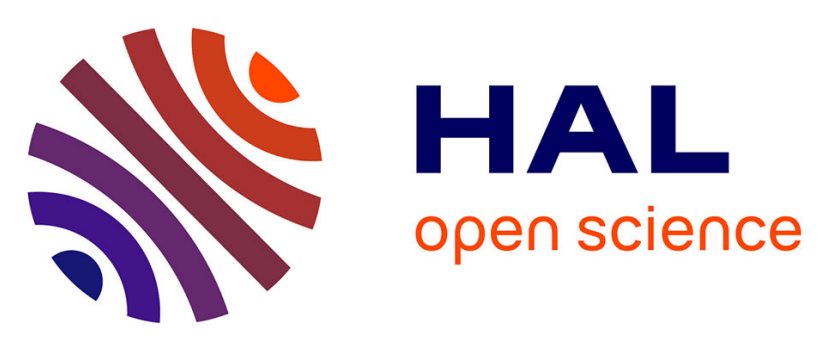

\title{
Alteration of CD8+ CD45RC[int/neg] regulatory T cells functions in Multiple Sclerosis and correlates with disease severity
}

Naïl Benallegue, Bryan Nicol, Séverine Bézie, Hadrien Regue, Nadège Vimont, Léa Flippe, Alexandra Garcia, David A. Laplaud, Carole Guillonneau

\section{To cite this version:}

Naïl Benallegue, Bryan Nicol, Séverine Bézie, Hadrien Regue, Nadège Vimont, et al.. Alteration of CD8+ CD45RC[int/neg] regulatory T cells functions in Multiple Sclerosis and correlates with disease severity. ECTRIMS 2018 (34th congress of the european committee for treatment and research in Multiple Sclerosis), Oct 2018, Berlin, Germany. inserm-02159755

\section{HAL Id: inserm-02159755 https://www.hal.inserm.fr/inserm-02159755}

Submitted on 19 Jun 2019

HAL is a multi-disciplinary open access archive for the deposit and dissemination of scientific research documents, whether they are published or not. The documents may come from teaching and research institutions in France or abroad, or from public or private research centers.
L'archive ouverte pluridisciplinaire HAL, est destinée au dépôt et à la diffusion de documents scientifiques de niveau recherche, publiés ou non, émanant des établissements d'enseignement et de recherche français ou étrangers, des laboratoires publics ou privés. 


\title{
Alteration of $\mathrm{CD} 8+\mathrm{CD} 45 \mathrm{RC} \mathrm{C}^{\text {int/neg }}$ regulatory $\mathrm{T}$ cells functions in Multiple Sclerosis and correlates with disease severity
}

\author{
Naïl Benalleque ${ }^{1,2,3,4}$, Bryan Nicol ${ }^{1,2,3,4}$, Séverine Bézie ${ }^{1,2,3}$, Hadrien Regue ${ }^{1,2,3}$, Nadège Vimont ${ }^{1,2,3}$, Léa Flippe ${ }^{1,2,3}$, \\ Alexandra Garcia ${ }^{1,2,3}$, David A. Laplaud ${ }^{1,2,3,4}$ and Carole Guillonneau ${ }^{1,2,3,4}$ \\ ${ }^{1}$ Center for Research in Transplantation and Immunology, INSERM, Université de Nantes, Nantes, France; ' ${ }^{2}$ nstitut de Transplantation Urologie Néphrologie (ITUN), CHU Nantes, Nantes, France; ${ }^{3}$ LabEx
} GO "Immunotherapy, Graft, Oncology", Nantes, France; ${ }^{4}$ co-authors

\section{BACKGROUND}

Autoimmune diseases can develop following pathological activation of autoreactive effector cells and/or, alternatively, after weakening of self-protective regulatory mechanisms. Most of the studies have focused on CD4+ Tregs and the role of CD8+ Tregs in Multiple Sclerosis (MS) remains largely unexplored. We previously reported the suppressive properties of rat and human CD8+CD45RCint/neg Treg cells, expressing Foxp3 and acting through IFNg, TGFb and IL34 cytokines (Guillonneau, JCl, 2007; Bézie, JCl, 2015, Bézie, Front. Immunol., 2018). Thus, their potency of suppression make them strong candidates of disruptive immune tolerance, especially in MS where $C D 8^{+} T$ cells play a major role. Thus, the overreaching goal of this study is to define the role of CD8 ${ }^{+}$regulatory T cell in MS pathogenesis

\section{MATERIAL \& METHODS}

56 untreated relapsing-remitting MS patients and 52 age- and gender-matched healthy volunteers (HV) were recruited. - Tregs were defined as $\mathrm{CD}^{+} \mathrm{CD}^{+}$(or $\left.\mathrm{CD} 4{ }^{-}\right) \mathrm{CD} 161^{\text {low }} \mathrm{V}_{\alpha} 7^{-} \mathrm{CD} 45 \mathrm{R} \mathrm{C}^{\text {intheg }} \mathrm{T}$ cells. MAIT cells were excluded from all analysis.

- Staining: T cells were stimulated or not $5 \mathrm{~h}$ with PMA+ionomycin including $4 \mathrm{~h}$ with BFA before FACS depending on the marker investigated. - Transcriptomic analysis: 3'-Digital Gene Expression Sequencing was performed on unstimulated cells. Analysis was performed using R packages and KEGG, Reactome and Gene Ontology databases for Gene Set Enrichment Analysis (GSEA).

\section{CD8+CD45RCINT TREGS FREQUENCY IN BLOOD IS REDUCED DURING EXACERBATION WHEREAS} CD8+CD45RCNEG TREGS ARE MORE FREQUENT WITH ENHANCED SUPPRESSIVE FUNCTIONS

CD8+CD45RC ${ }^{\text {int } / \text { neg }}$ CD8 ${ }^{+}$CD45RC int

Suppression assay

CD8 ${ }^{+}$CD45RC int

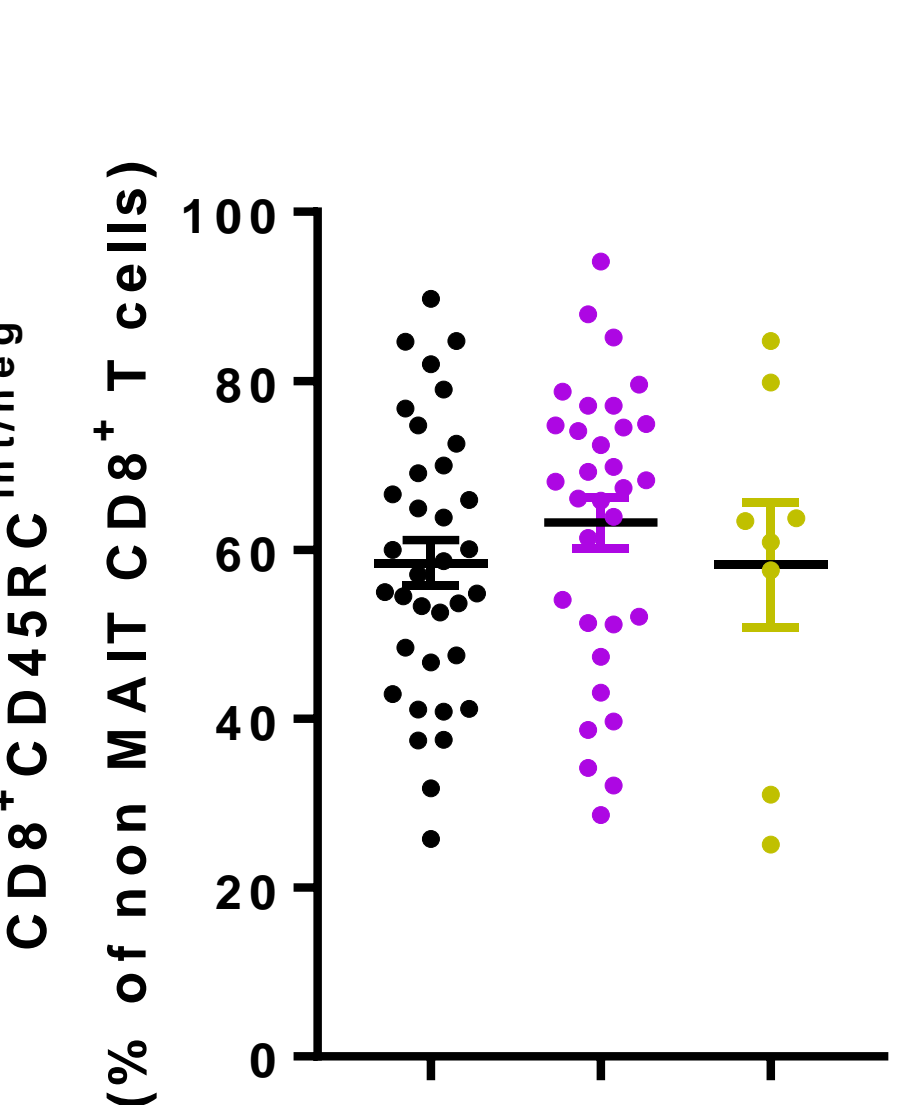

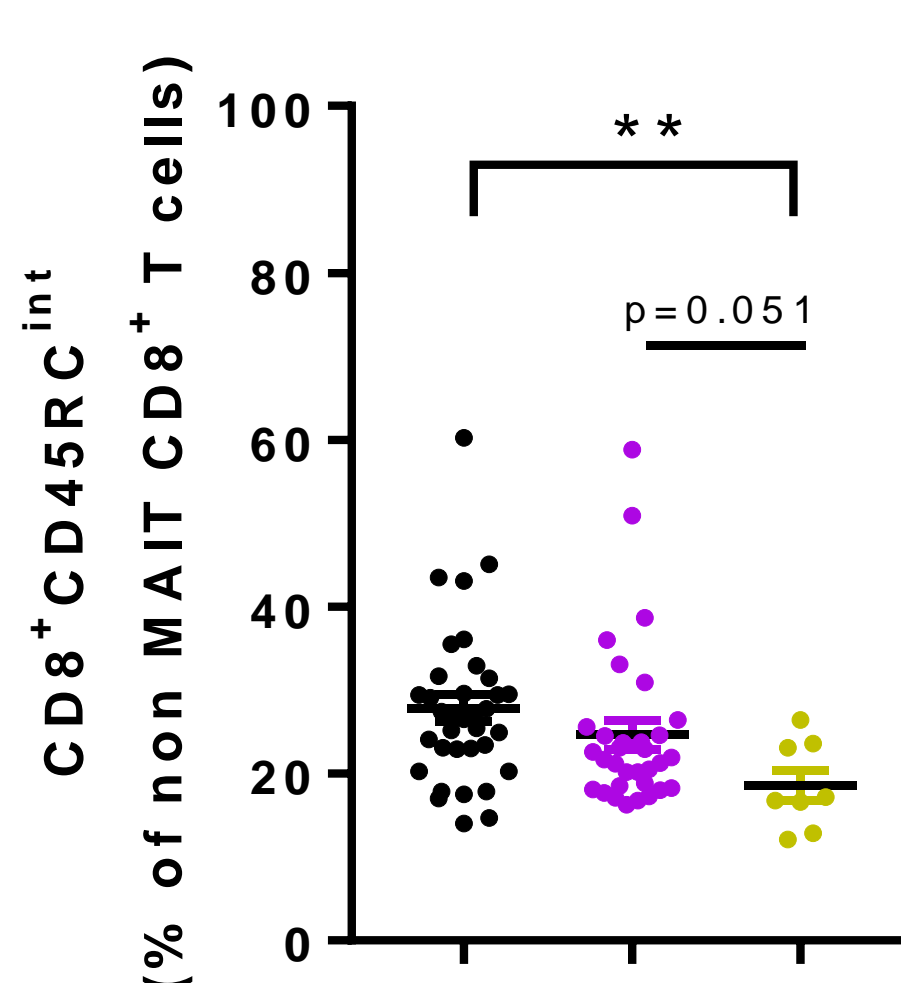

$\mathrm{CD} 8{ }^{+} \mathrm{CD} 45 \mathrm{RC}^{\mathrm{e}}$
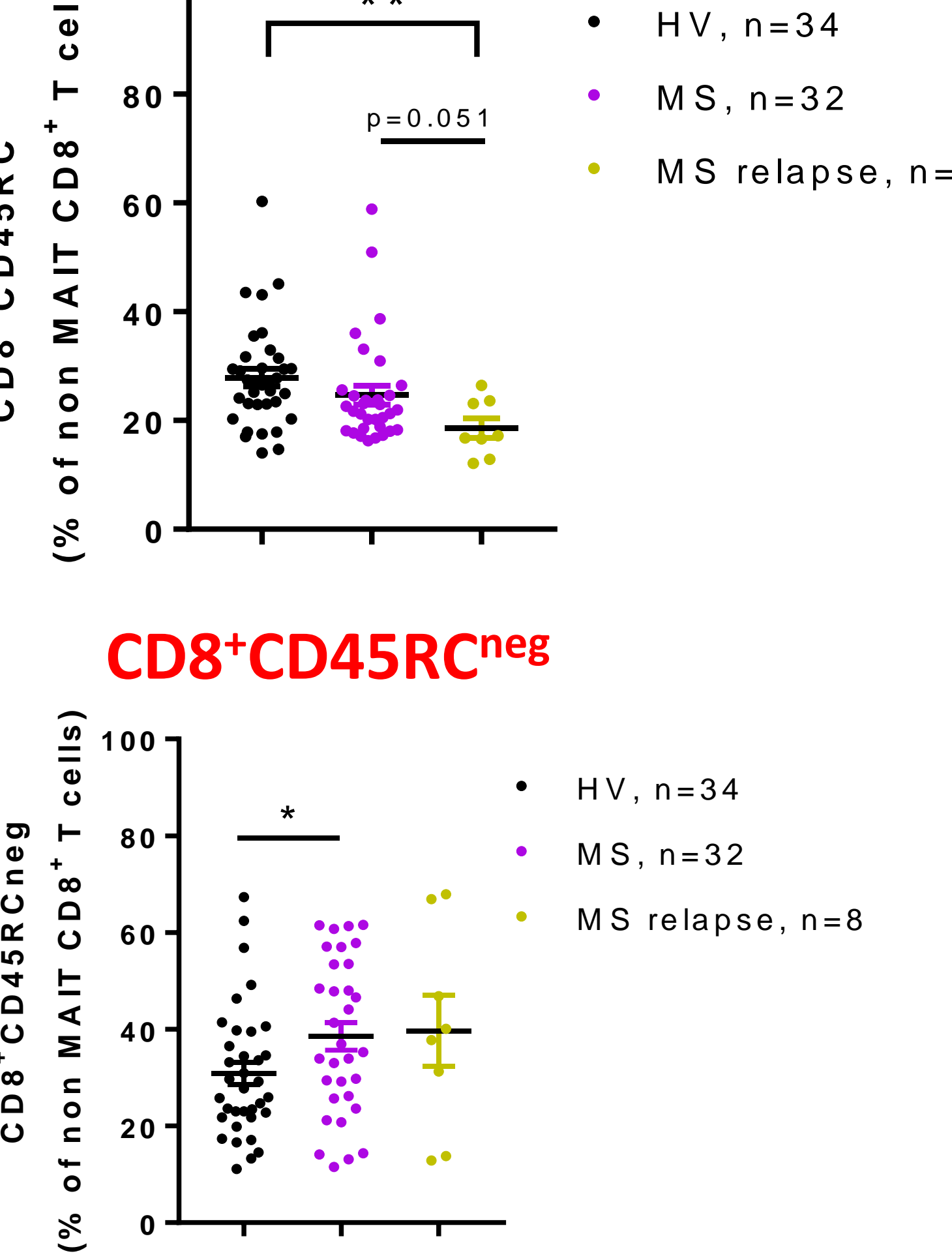
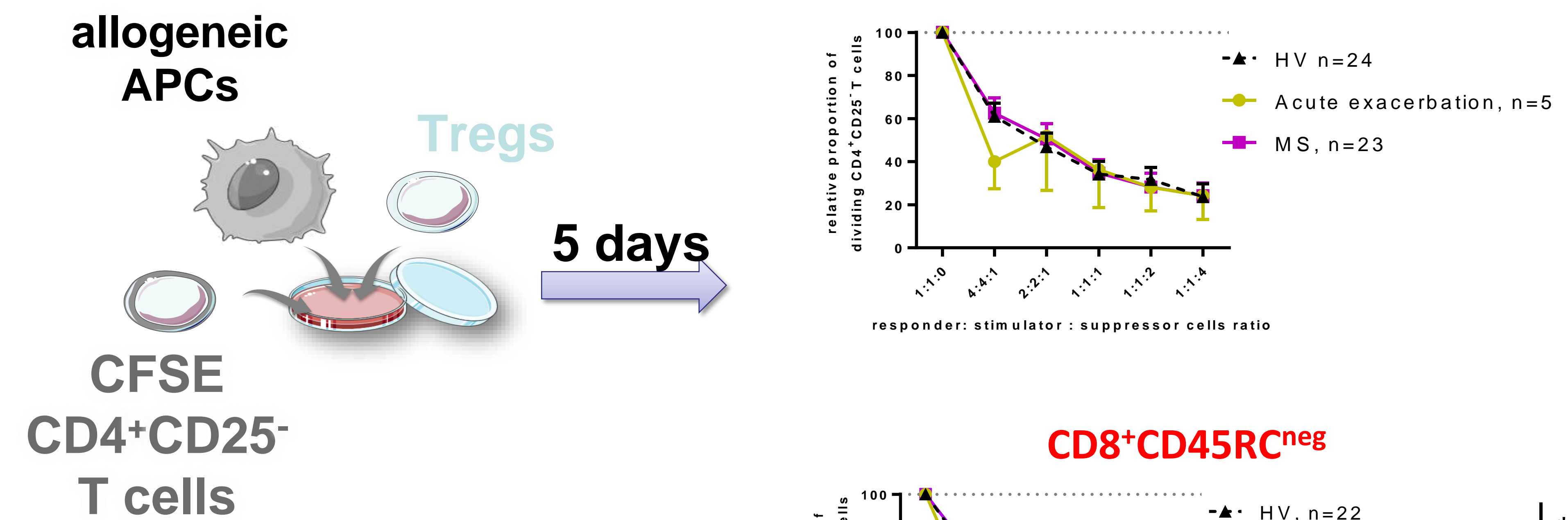

CD8+CD45RCneg

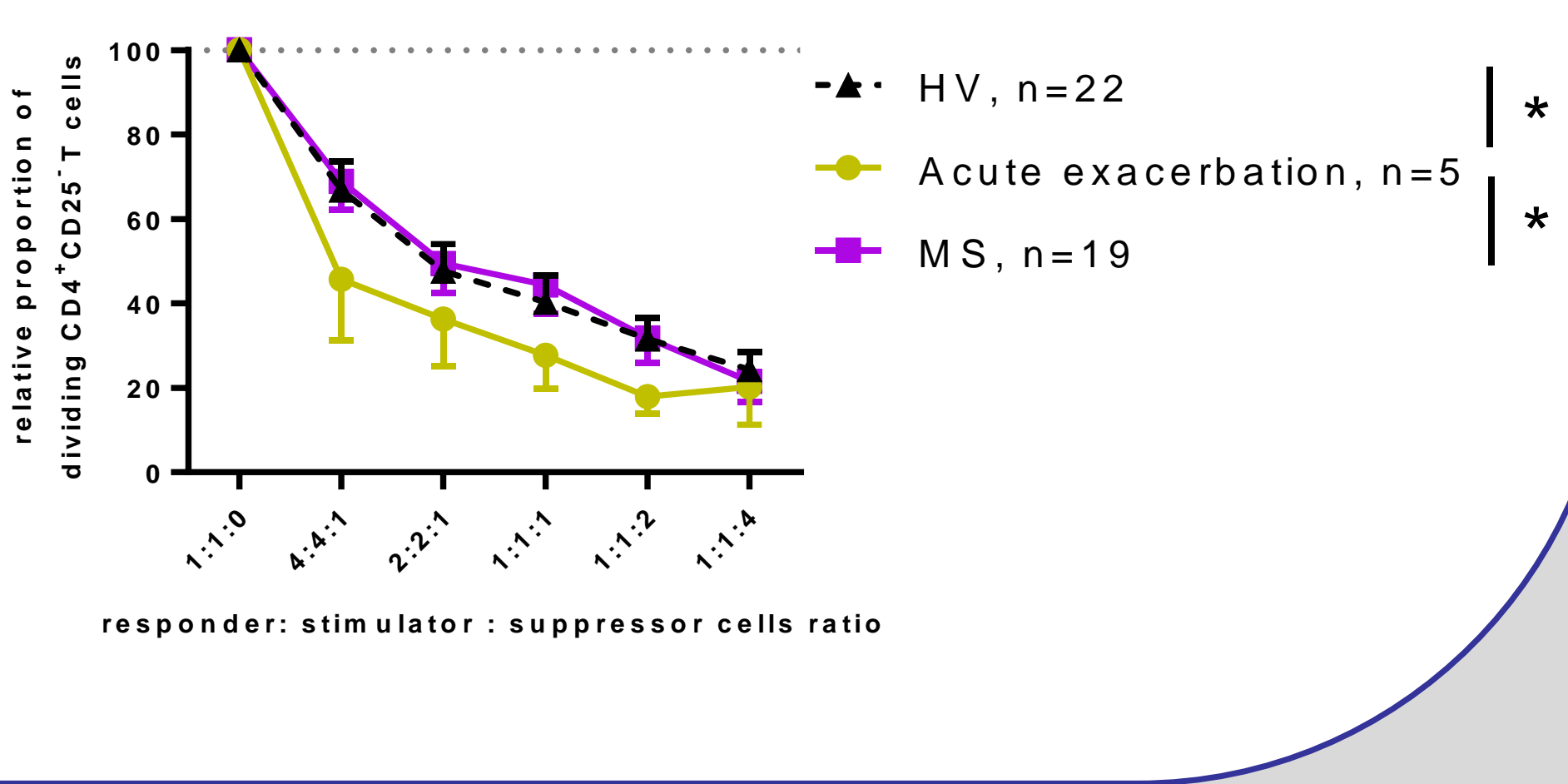

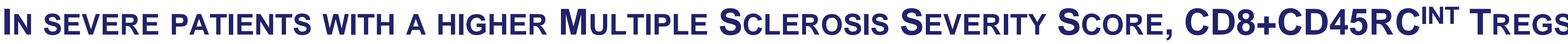
FUNCTION IS IMPAIRED

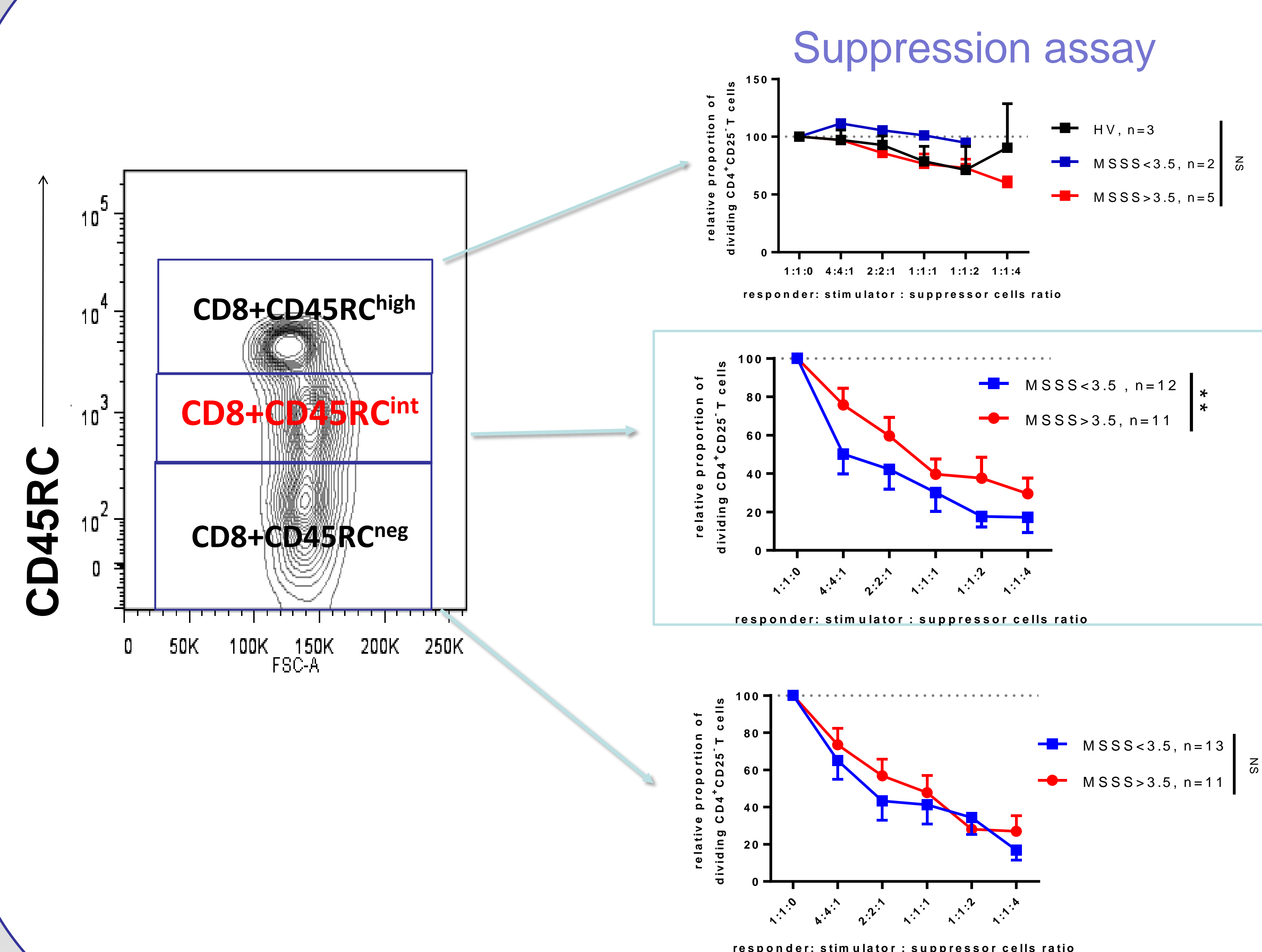

Transcriptomic Analysis (GSEA)

Regulation of Inflammatory Cytokine-mediated response Signaling Pathway

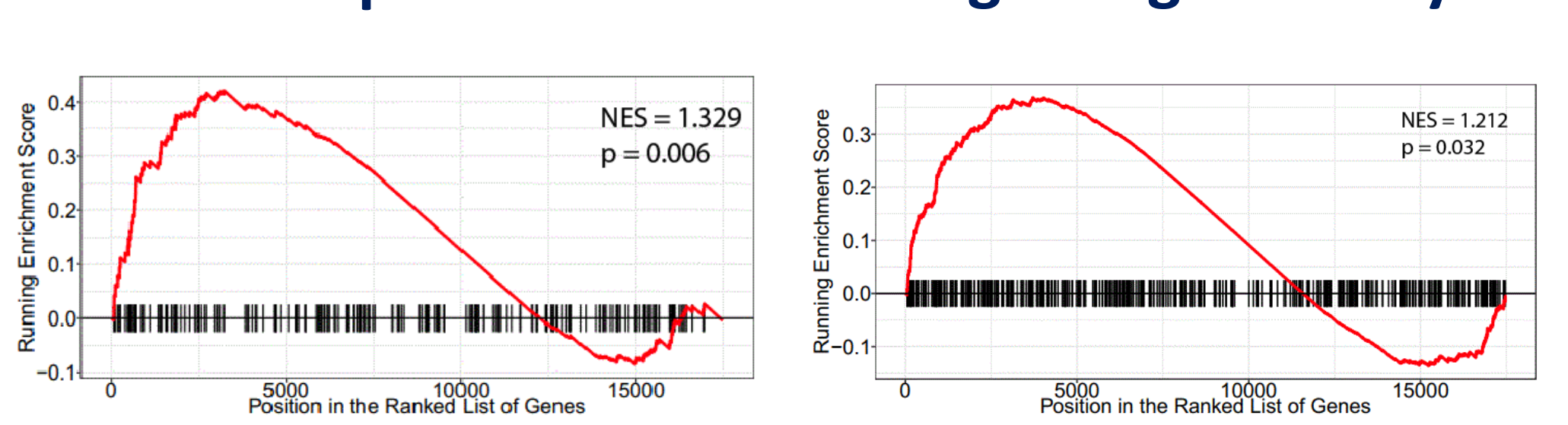

response pathways are overrepresented in s as compared to

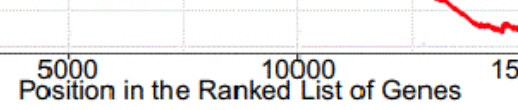
MSSS $>3,5$ patients

\section{Flow Cytometry Analysis}

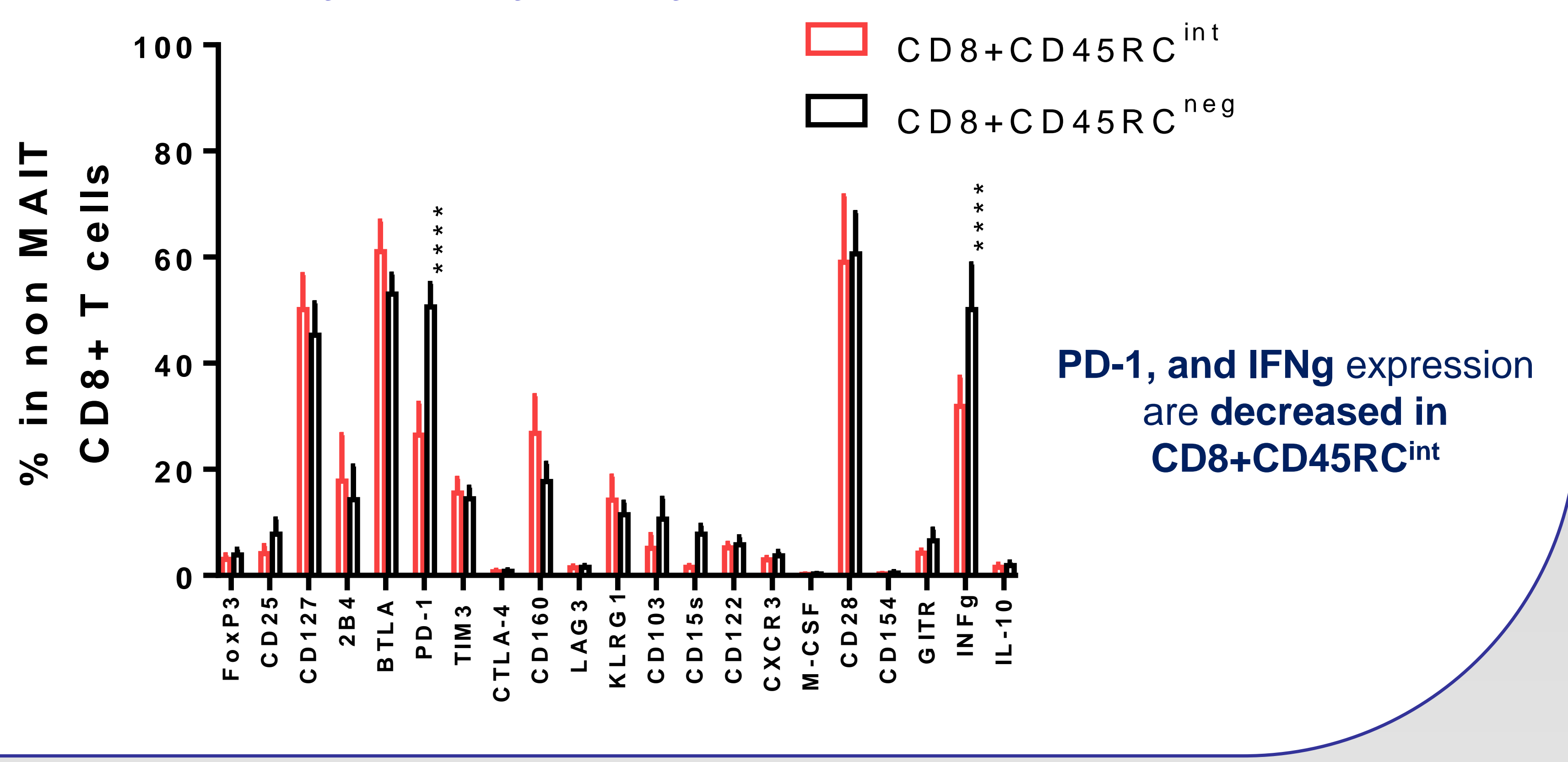

\section{CONCLUSION}

For the first time, we demonstrate an impairment of CD8+CD45RCint Tregs in MS.

We propose to define two populations of CD8+CD45RC Tregs:

- $\quad$ CD8+CD45RCint are dysfunctional in severe MS patients and less frequent during exacerbations

- $\quad$ CD8+CD45RCneg Tregs react properly to inflammation with enhanced regulatory functions during exacerbations

We suggest CD8+CD45RCint/neg $T$ cells and subsets may be potential therapeutic targets and prognostic tools in MS 